
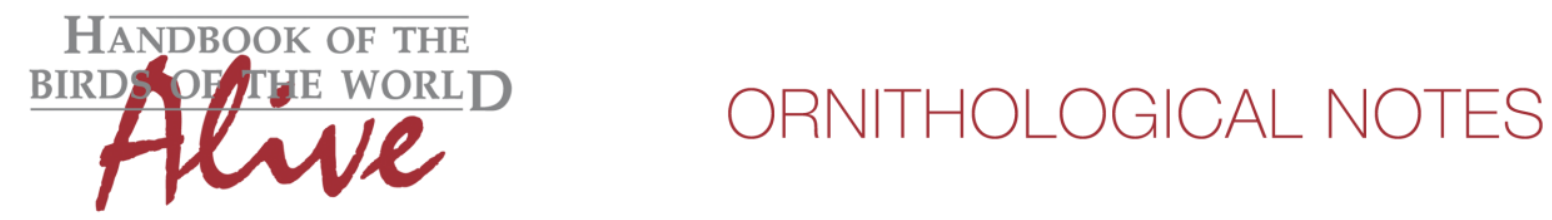

\title{
Notes on the vocalizations of Northern Barred Woodcreeper (Dendrocolaptes sanctithomae)
}

Peter Boesman

In the following we briefly analyze and compare song of the different races of Northern Barred Woodcreeper (Dendrocolaptes sanctithomae). We also try to quantify the extent of any vocal differences using the criteria proposed by Tobias et al. (2010), as a support for taxonomic review. We have made use of sound recordings available on-line from Xeno Canto (XC) and Macaulay Library (ML).

It would seem that we can clearly distinguish two vocal groups:

Group 1: North and west (includes D. s. sheffleri, D. s. sanctithomae and D. s. hesperius). Song is a characteristic series of 5-10 whistles which are markedly upslurred. When agitated, the series may count more notes with fast acceleration at end. Bottom frequency of every note equal or slightly higher than previous note (Fig. 1). (No recordings available of race sheffleri but reportedly similar (Howell 1995)).
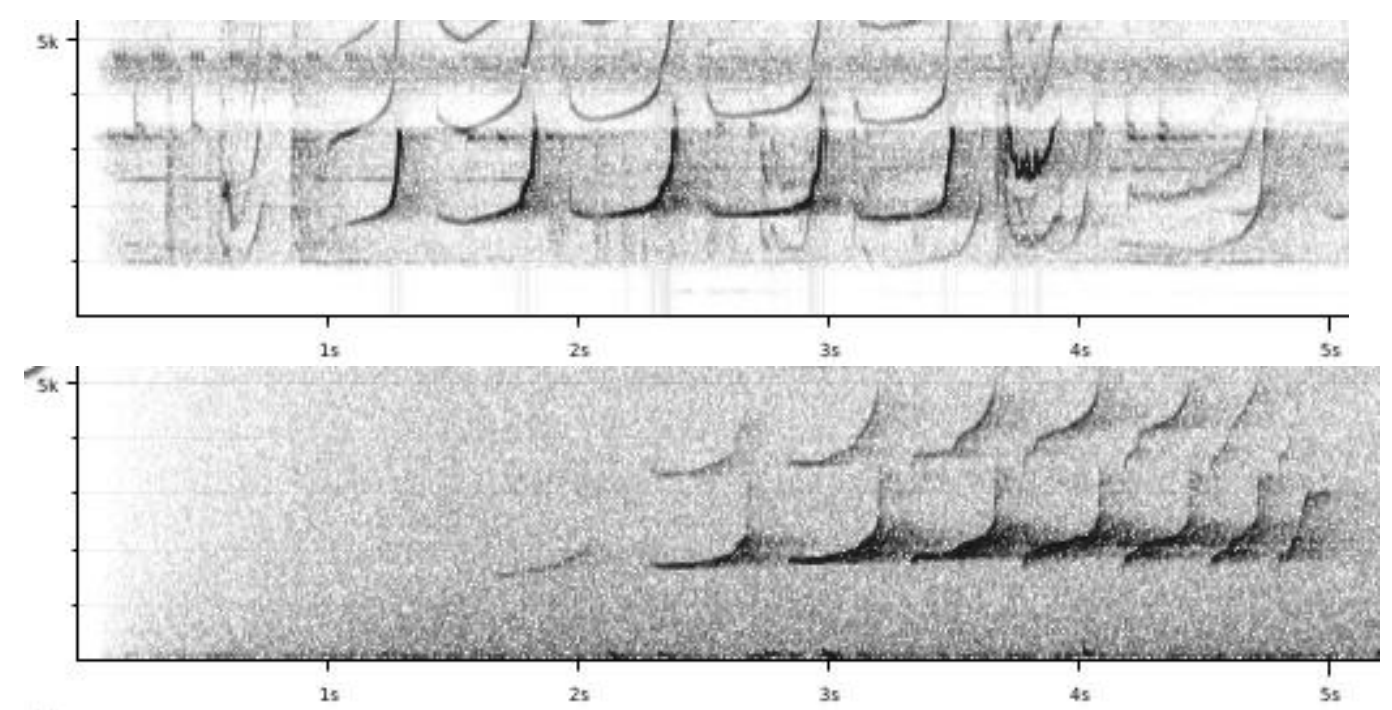

Figure 1: examples of song of 'North and west group'

Measurements:

max. freq first note: min freq first note: $2400-4800 \mathrm{~Hz}$ max freq last note: $1400-1800 \mathrm{~Hz}$ $\min$ freq last note: note length: $3000-4800 \mathrm{~Hz}$ overall freq range: $1500-1900 \mathrm{~Hz}$ c. $0.30-0.50 \mathrm{~s}$ c. $3500 \mathrm{~Hz}$ 

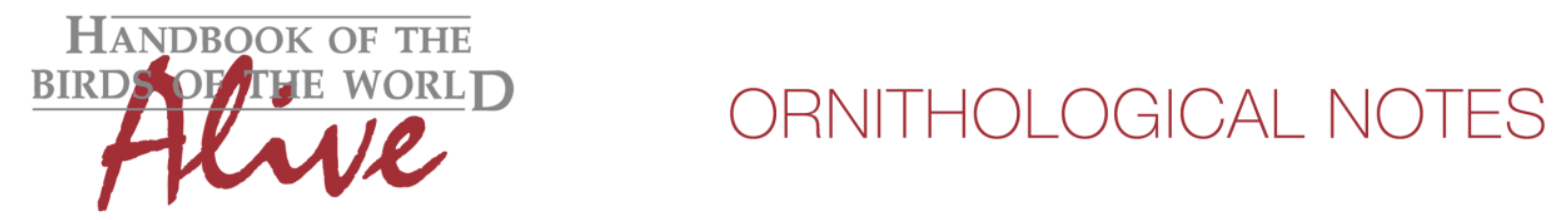

Group 2: East (D.s.punctipectus)

We have found 3 recordings from Zulia, Venezuela by P. Schwartz (ML65197, 65198 and 65400). There are apparently no recordings from $\mathrm{N}$ Colombia where this taxon may meet race sanctithomae.

Song of punctipectus is clearly different from all previous races: a series of 4-10 whistles which start flat in pitch and get more and more overslurred. Average note frequency stable or slightly rising over entire series (Fig. 2). When agitated, the series may count more notes with fast acceleration at end.

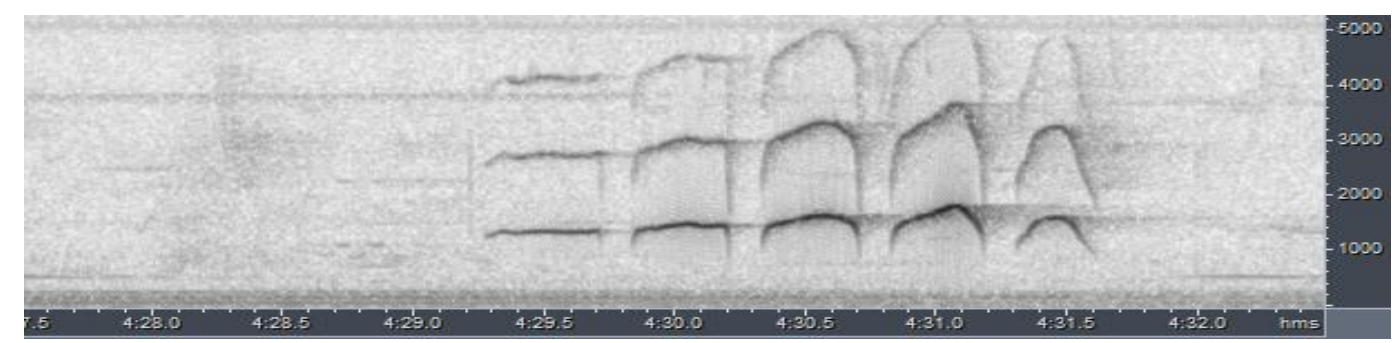

Figure 2: song of punctipectus

Measurements:

max. freq first note:

min freq first note:

$1400 \mathrm{~Hz}$

max freq last note

$1300-1400 \mathrm{~Hz}$

$\min$ freq last note:

note length:

$1900-2400 \mathrm{~Hz}$

$1000-1100 \mathrm{~Hz}$

overall freq range:

c. $0.35-0.45 \mathrm{~s}$

c. $1400 \mathrm{~Hz}$

Main quantifiable differences are the max. frequency and frequency range of the first note (much lower in punctipectus, score 3), max. frequency and frequency range over entire series of notes (much lower in punctipectus, score 2) and the shape of notes (flat or overslurred vs. upslurred), which would lead to a total score of 5 according to Tobias criteria.

A note of caution however: the result is based on just a few recordings of punctipectus. It is desirable to obtain sound recordings from $\mathrm{N}$ Colombia, to confirm the above findings and to investigate whether there is a contact zone with sanctithomae.

Overall, vocal difference in song between the two groups is quite clear, and although it is less striking then compared to the third group which is part of this complex (D. certia), it is nevertheless significant.

This note was finalized on 1st April 2015, using sound recordings available on-line th that moment. We would like to thank in particular the many sound recordists who placed their recordings for this species on XC and ML. 


\section{References}

Howell, S.N.G, Webb, S. (1995). A guide to the birds of Mexico and Northern Central America. Oxford University Press, New York.

Tobias, J.A., Seddon, N., Spottiswoode, C.N., Pilgrim, J.D., Fishpool, L.D.C. \& Collar, N.J. (2010). Quantitative criteria for species delimitation. Ibis 152(4): 724-746.

\section{Recommended citation}

Boesman, P. (2016). Notes on the vocalizations of Northern Barred Woodcreeper (Dendrocolaptes sanctithomae). HBW Alive Ornithological Note 81. In: Handbook of the Birds of the World Alive. Lynx Edicions, Barcelona. (retrieved from http://www.hbw.com/node/931975 on 16 July 2016). 